ISSN 1678-3921

Journal homepage: www.embrapa.br/pab

For manuscript submission and journal contents, access: www.scielo.br/pab
Helton Santos Pereira(1凶) (iD, Fabiana Rocha Mendonça( ${ }^{(2)}$, Ludivina Lima Rodrigues ${ }^{(2)}$ (iD, Leonardo Cunha Melo(1) (D), Patrícia Guimarães Santos Melo(2) (DD, Luís Cláudio de Faria(1) (D), Antônio Félix da Costa(3) (iD, Hélio Wilson Lemos de Carvalho(4) (D), Israel Alexandre Pereira Filho(5) (D) and Válter Martins de Almeida ${ }^{(6)}$ (iD)

(1) Embrapa Arroz e Feijão, Rodovia GO-462, Km 12, Fazenda Capivara, Zona Rural, Caixa Postal 179, CEP 75375-000 Santo Antônio de Goiás, GO, Brazil. E-mail: helton.pereira@embrapa.br, leonardo.melo@embrapa.br, luis.faria@embrapa.br

(2) Universidade Federal de Goiás, Campus Samambaia, Avenida Esperança, s/no, CEP 74690-900 Goiânia, GO, Brazil. E-mail: fr.mendonca@hotmail.com, ludivina_rodrigues@hotmail.com, pgsantos@ufg.br

(3) Instituto Agronômico de Pernambuco, Avenida General San Martin, № 1.371, Bongi, CEP 50761-000 Recife, PE, Brazil. E-mail: felix.antonio@ipa.br

(4) Embrapa Tabuleiros Costeiros, Avenida Beira Mar, ํㅜ 3.250, Jardins, CEP 49025-040 Aracaju, SE, Brazil. E-mail: helio.carvalho@embrapa.br

(5) Embrapa Milho e Sorgo, Rodovia MG-424, Km 45, Caixa Postal 285 ou 151, CEP 35701-970 Sete Lagoas, MG, Brazil. E-mail: israel.pereira@embrapa.br

(6) Empresa Mato-grossense de Pesquisa, Assistência e Extensão Rural, Rua Cinquenta e Cinco, № 454, Boa Esperança, CEP 78068-720 Cuiabá, MT, Brazil. E-mail: almeida-walter@uol.com.br

$\bowtie$ Corresponding author

\section{Selection of carioca common bean lines with slow darkening}

\begin{abstract}
The objective of this work was to evaluate the interaction between genotypes and environment for seed-coat darkening of common bean (Phaseolus vulgaris) seeds, in order to select lines that combine slow darkening, upright plants, resistance to lodging, and higher yield and 100-grain weight, with good adaptability and stability for these traits. Forty-four pre-selected lines, originating from crosses between one cultivar with slow darkening and prostrate plants and four cultivars with normal darkening and upright plants, were evaluated in field trials conducted in 15 environments (combinations of locations, crop seasons, and years). Considering the mean values, adaptability, and stability for each isolated trait, most of the lines presented satisfactory performance: $75 \%$ for slow darkening, $48 \%$ for high yield, $59 \%$ for upright plants, $84 \%$ for resistance to lodging, and $68 \%$ for 100 -grain weight. The effects of environments and of the genotype by environment interaction are important for the five studied traits. The CNFC 16754 and CNFC 16820 lines present slow seed-coat darkening, high yield and 100-grain weight, more upright plant architecture, and greater resistance to lodging, besides high adaptability and stability for these traits, which shows their potential for recommendation as new cultivars and confirms that it is possible to join desirable phenotypes for the five traits evaluated.
\end{abstract}

Index terms: Phaseolus vulgaris, genotype by environment interaction, resistance to lodging, stability, upright architecture.

\section{Seleção de linhagens de feijão carioca com escurecimento lento}

Resumo - O objetivo deste trabalho foi avaliar a interação entre genótipos e ambientes para o escurecimento de grãos de feijão carioca (Phaseolus vulgaris), a fim de selecionar linhagens que associem escurecimento lento, arquitetura ereta, tolerância ao acamamento, e maior produtividade e peso de 100 grãos, com boa adaptabilidade e estabilidade para esses caracteres. Foram avaliadas 44 linhagens pré-selecionadas, oriundas de cruzamentos entre uma cultivar com escurecimento lento e arquitetura prostrada e quatro cultivares com escurecimento normal e arquitetura ereta, em experimentos de campo conduzidos em 15 ambientes (combinações de locais, épocas de semeadura e anos). Ao se considerar as médias, a adaptabilidade e a estabilidade para cada caráter isoladamente, a maior parte das linhagens apresentou desempenho satisfatório: $75 \%$ para escurecimento lento, $48 \%$ para alta produtividade, $59 \%$ para arquitetura ereta, $84 \%$ para tolerância ao acamamento e $68 \%$ para peso de 100 grãos. Os efeitos dos ambientes e da interação entre genótipos e ambientes são importantes para os cinco caracteres estudados. As linhagens CNFC 16754 e CNFC 16820 apresentam escurecimento lento dos grãos, alta produtividade e peso de 100 grãos, plantas mais eretas e alta tolerância ao acamamento, além de alta adaptabilidade e estabilidade para esses caracteres, o que mostra o seu potencial para recomendação como novas cultivares e 
Received

March 09, 2021

Accepted

August 02, 2021

How to cite

PEREIRA, H.S.; MENDONCA, F.R.; RODRIGUES, L.L.; MELO, L.C.; MELO, P.G.S.; FARIA, L.C. de; COSTA, A.F. da; CARVALHO, H.W.L. de; PEREIRA FILHO,

I.A.; ALMEIDA, .V.M. de.. Selection of carioca common bean lines with slow darkening. Pesquisa Agropecuária Brasileira, v.56, e02471, 2021. DOI: https://doi.org/10.1590/ S1678-3921.pab2021.v56.02471. confirma que é possível reunir fenótipos desejáveis para os cinco caracteres avaliados.

Termos para indexação: Phaseolus vulgaris, interação entre genótipos e ambientes, resistência ao acamamento, estabilidade, arquitetura ereta.

\section{Introduction}

Brazil is among the countries that most produce common bean (Phaseolus vulgaris L.) (FAO, 2021), with an annual production of around 2,7 million tons (Embrapa, 2021). The "carioca" type - creamcolored seed coat with brown stripes - of common bean is preferred in the country and represents $75 \%$ of the market (Pereira et al., 2021).

During the period between grain harvest and sale in the market, high temperature and humidity conditions accelerate the oxidation reaction of the condensed tannins present in the seed coat of the carioca grain, which leads to darkening of the beige tones of the seed coat, lowering the commercial value of the grain (Junk-Knievel et al., 2008; Silva et al., 2008, 2014, 2018; Alvares et al., 2016; Coutin et al., 2017; Erfatpour et al., 2018). Consumers associate dark seed coats in common bean with a low-quality product that is hard to cook (long cooking time) and has a hard shell (high bean firmness).

Junk-Knievel et al. (2008), working with pinto bean, and Silva et al. (2008), with carioca bean, each concluded that seed-coat darkening is under monogenic control, with dominance of the allele that regulates normal darkening. The gene identified by Junk-Knievel et al. (2008) was called $S d$ (slow darkening). After that, Elsadr et al. (2011) reported the presence of two genes controlling seed-coat darkening, with recessive epistasis, with one of the genes $(J)$ being responsible for darkening or lack of darkening of the seed coat and the other $(S d)$, for speed of darkening. Alvares et al. (2019) confirmed the monogenic segregation reported by Silva et al. (2008) and found that the gene responsible for darkening in carioca bean and pinto bean may be the same, as shown through the use of a molecular marker. Using an allelism test, Rodrigues et al. (2019) also observed that the $S d$ gene identified in pinto bean is the same one present in carioca bean. In addition, several authors found high heritability estimates (Silva et al., 2014; Alvares et al., 2016), indicating favorable conditions for the selection of lines with slow seedcoat darkening.

In Brazil, a few common bean cultivars show slow seed-coat darkening, but grow into prostrate plants (Alvares et al., 2020). Upright plants are preferable because they create an environment unfavorable to the disease and allow mechanized harvest with less grain loss and with better grain quality (Alvares et al., 2016). However, the cultivars available with upright plant architecture have normal seed-coat darkening. Therefore, combining upright plant architecture and slow seed-coat darkening in the same cultivar would be advantageous. Other desirable phenotypes, such as high yield and larger bean size, are also 
important for the good acceptance of a new cultivar (Pereira et al., 2017a; Arns et al., 2018).

Common bean is grown under diverse agroclimatic conditions, and, for this reason, the genotype by environment interaction can affect the selection of superior lines. Under those conditions, analyses of adaptability and stability can assist in identifying promising lines. For grain yield in common bean, several studies have confirmed the importance of the genotype by environment interaction (Alvares et al., 2016; Corrêa et al., 2016; Delfini et al., 2018; Di Prado et al., 2019). However, works of this type are not frequent for seed-coat darkening, 100-grain weight, plant architecture, and resistance to lodging (Alvares et al., 2016; Delfini et al., 2018; Silva et al., 2018).

The objective of this work was to evaluate the interaction between genotypes and environment for seed-coat darkening of common bean seeds, in order to select lines that combine slow darkening, upright plants, resistance to lodging, and higher yield and 100 -grain weight, with good adaptability and stability for these traits.

\section{Materials and Methods}

The lines used were obtained from Embrapa Arroz e Feijão, located in the municipality of Santo Antônio de Goiás, in the state of Goiás, Brazil. Initially, Silva et al. (2014) obtained segregating populations from crosses between the BRSMG Madrepérola carioca-type cultivar, with slow seed-coat darkening and prostrate plants, and ten cultivars with normal seed-coat darkening and upright plants. These populations were evaluated and the following four were selected to obtain lines: BRSMG Madrepérola $\times$ BRS Estilo, BRSMG Madrepérola $\times$ BRS Cometa, BRSMG Madrepérola $\times$ BRS Notável, and BRSMG Madrepérola $\times$ BRS Sublime. The 55 lines obtained from each population were evaluated in three environments for seed-coat darkening, yield, and plant architecture (Alvares et al., 2016, 2019). Based on these results, 11 lines were selected from each of the four populations, totaling 44 lines.

In the present study, these 44 lines and the five parents were evaluated in trials set up in 15 environments in different locations in Brazil: Anápolis, in the state of Goiás; Santo Antônio de Goiás, in the state of Goiás; Brasília, in Distrito Federal; Cáceres, in the state of
Mato Grosso; Belém de São Francisco, in the state of Pernambuco; Carira, in the state of Sergipe; Sete Lagoas, in the state of Minas Gerais; Uberlândia, in the state of Minas Gerais; and Ponta Grossa, in the state of Paraná. Each environment was a combination of location, crop season (rainy, dry, and winter), and year $(2012,2013$, and 2014). The trials were conducted in a $7 \times 7$ triple lattice design, with plots consisting of two 3 $\mathrm{m}$ length rows with a spacing of $0.50 \mathrm{~m}$ between rows. Management practices were carried out according to the recommendations for the common bean crop in each region, but without disease control (Melo, 2009). The assessed traits were seed-coat darkening, yield and 100 -grain weight, plant architecture, and resistance to lodging.

Plant architecture and resistance to lodging were evaluated according to a scoring scale, ranging from 1 to 9 , where 1 refers to phenotypes ideal for mechanized harvest and 9, to phenotypes that cannot be harvested by machines (Melo, 2009). To estimate yield, all the plants of the plot were harvested and threshed; the grains were weighed $\left(\mathrm{kg} \mathrm{ha}^{-1}\right)$ after being dried to $13 \%$ moisture. The 100-grain weight was determined by weighing a random sample of 100 beans.

Seed-coat darkening was assessed using the method proposed by Silva et al. (2008) and adapted by Silva et al. (2014), through a scoring scale, ranging from 1 (very light-colored beans) to 5 (dark beans), 90 days after harvest. After harvest, a grain sample from each plot was placed in perforated transparent plastic packaging, and, then, the samples were stored in a shed at ambient temperature and humidity.

Individual and joint analyses of variance were performed for each trait. The homogeneity of residual variances was checked by observing the ratio between the maximum and minimum values of the experimental mean square errors (Pimentel-Gomes, 2000). Means were compared by the Scott-Knott means clustering test, at $10 \%$ probability. Selective accuracy was also estimated (Resende \& Duarte 2007), a measurement of experimental accuracy not affected by the mean of the environments.

Analyses of stability were also performed for the five traits evaluated, adopting the method of Nunes et al. (2005), also described by Ramalho et al. (2012), using the SAS software (SAS Institute Inc., Cary, NC, USA). The method of Nunes et al. (2005) standardizes the 
mean values of the lines in the different environments by the expression:

$$
\mathrm{z}_{\mathrm{ij}}=\left(\overline{\mathrm{y}}_{\mathrm{ij}}-\overline{\mathrm{y}}_{\mathrm{j}}\right) / \mathrm{S}_{\mathrm{j}},
$$

where $z_{i j}$ is the value of the standardized variable corresponding to cultivar $i$ in environment $j ; \bar{y}_{i j}$ is the mean value of cultivar $i$ in environment $j ; \bar{y}_{j}$ is the mean value of environment $\mathrm{j}$; and $\mathrm{S}_{\mathrm{j}}$ is the phenotypic standard deviation among the means of the cultivars in environment $\mathrm{j}$, given by

$$
S_{j}=\sqrt{\sum_{i=1}^{t} \bar{y}_{i j}-\bar{y}_{j} / t}-1,
$$

where $\mathrm{t}$ is the number of treatments. Since the standardized variable $z_{i j}$ has positive and negative values, in order to facilitate visualization in graphics, a constant is added to make these values positive. Therefore, $\bar{Z}_{\mathrm{i}}$ is the mean of the values of $z_{i j}$ for cultivar $\mathrm{i}$ in $\mathrm{k}$ environments, which corresponds to the measurement of adaptation of cultivar i. The coefficient of variation of $\mathrm{z}_{\mathrm{ij}}\left(\mathrm{CVZ}_{\mathrm{ij}}\right)$ for cultivar $\mathrm{i}$ in $\mathrm{k}$ environments corresponds to the measurement of stability.

The criterion for selection of lines with good adaptability was $Z_{i}>4.0$, through clustering of the mean values. For the lines to be considered as having good stability, different criteria were adopted for each trait: $\mathrm{CV}_{\mathrm{i}}<15 \%$, for seed-coat darkening and 100 -grain weight; $\mathrm{CV}_{\mathrm{i}}<20 \%$, for plant architecture and resistance to lodging; and $\mathrm{CV}_{\mathrm{i}}<25 \%$, for grain yield.

For the selection of promising lines, the mean values, adaptability, and stability of the traits were considered, using the weight-free and parameter-free index (Elston, 1963), which pre-establishes minimum or maximum values $\left(\mathrm{k}_{\mathrm{i}}\right)$ for the traits under selection. For the mean values of the lines, the values of $\mathrm{k}_{\mathrm{i}}$ established were the overall means for each trait: less than 3.0 for seed-coat darkening, greater than 2,994 $\mathrm{kg} \mathrm{ha}^{-1}$ for yield, less than 5.1 for plant architecture, less than 4.9 for resistance to lodging, and greater than $24 \mathrm{~g}$ for 100-grain weight.

\section{Results and Discussion}

The estimates of the coefficient of variation in the environments ranged from 9.8 to $20.7 \%$ for seedcoat darkening, 10.9 to $20.6 \%$ for yield, 8.9 to $13.8 \%$ for plant architecture, 11.3 to $18.0 \%$ for resistance to lodging, and 3.8 to $5.7 \%$ for 100 -grain weight (Table 1), which were considered suitable and indicative of good experimental accuracy (Alvares et al., 2016; Silva et al., 2018). In addition, the estimates of selective accuracy ranged from 0.80 to 0.97 for seed-coat darkening, 0.67 to 0.90 for yield, 0.75 to 0.92 for plant architecture, 0.67 to 0.91 for resistance to lodging, and 0.84 to 0.96 for 100 -grain weight; $96 \%$ of these estimates were considered high or very high, confirming good experimental accuracy (Resende \& Duarte, 2007).

The results of the individual (Table 1) and joint analyses (Table 2) showed differences among genotypes and among environments for all traits, which has been reported in other studies on common bean (Alvares et al., 2016; Corrêa et al., 2016; Delfini et al., 2018; Silva et al., 2018). Even with the previous selection of lines (Alvares et al., 2016), there was still variability among them within each population.

The environment with lower seed-coat darkening (2.4) was Uberlândia, in the state of Minas Gerais, in 2013, in the dry season, and the highest (4.2) was Carira, in the state of Sergipe, also in 2013, in the rainy season (Table 1). In general, the experiments conducted during the rainy crop season showed darker grains, which can be explained by the high humidity at harvest, accelerating the darkening of the grains; in the dry and winter crop seasons, harvesting is mostly done without the occurrence of precipitation. For yield, the mean values of the environments ranged from 1,562 to $5,303 \mathrm{~kg} \mathrm{ha}^{-1}$. The environments with the highest yields were Santo Antônio de Goiás, in the state of Goiás, in 2012, and Sete Lagoas, in the state of Minas Gerais, in 2013 , both in the winter crop season, which is usually characterized by the highest yields (Embrapa, 2021). However, the two worst means also occurred in this season, but in Cáceres, in the state of Mato Grosso, in the winters of 2013 and 2014, which can be explained by the low altitude and high temperatures of this location (Pereira et al., 2012). For the other traits, the mean values of the environments ranged from 4.5 to 5.7 for plant architecture, 4.5 to 5.5 for resistance to lodging, and 22.1 to $27.1 \mathrm{~g}$ for 100-grain weight, indicating a wide variation among environments.

This variation can be attributed both to the geographic data of the experimental locations, whose altitudes range from 118 to $1,171 \mathrm{~m}$, south latitudes from $08^{\circ} 45^{\prime} 14^{\prime \prime}$ to $25^{\circ} 05^{\prime} 42^{\prime \prime}$, and west longitudes 
from $37^{\circ} 42^{\prime} 04^{\prime \prime}$ to $57^{\circ} 40^{\prime} 44^{\prime \prime}$, and to the different crop seasons (rainy, dry, and winter) and years $(2012,2013$, and 2014) of evaluation.

A differentiated response of the genotypes was also detected in the different environments for all traits, due to the genotype by environment interaction (Table 2). Although the interaction for seed-coat darkening has been reported in the literature (Silva et al., 2014; Siqueira et al., 2014; Alvares et al., 2016), only a few environments have been evaluated. However, a larger number of environments is necessary for a more reliable selection of lines. The interaction between genotypes and environment has been frequently reported for yield (Alvares et al., 2016; Corrêa et al., 2016; Delfini et al., 2018; Di Prado et al., 2019), but less for plant architecture, resistance to lodging, and 100-grain weight (Alvares et al., 2016; Delfini et al., 2018; Silva et al., 2018).

When the interaction is significant, an option is to identify the best performing lines in each environment. However, when several traits and environments have to be considered to recommend new cultivars, the most common alternative for most cultures is to identify a few lines with broad adaptability and stability, through stability analyzes (Pereira et al., 2018; Souza et al., 2018). This way, it would be possible to indicate lines as new cultivars that could be used in a greater number of environments.

The cluster analysis for seed-coat darkening allowed classifying the lines in ten groups. Lines CNFC 16709 and CNFC 16871 showed good results, with mean values similar to that of the BRSMG Madrepérola check cultivar (Table 3). The second to the fifth clusters gathered 31 lines, considered to have the slow darkening trait, with mean values ranging from 2.1 to 3.0. The other 11 lines and four cultivars were classified as having normal seed-coat darkening. Therefore, $73 \%$ of the lines had bean grains with slow darkening after storage, showing the high efficiency of the selection made by Alvares et al. (2016). The BRS Notável and BRS Cometa cultivars had the darkest grains, with values of 4.8 and 4.9 , respectively.

Table 1. Summary of the individual analysis of variance for the evaluation of seed-coat darkening, yield, plant architecture, resistance to lodging, and 100-grain weight of 49 common bean (Phaseolus vulgaris) lines, evaluated in 15 environments in the states of Goiás (GO), Sergipe (SE), Pernambuco (PE), Paraná (PR), Minas Gerais (MG), as well as in Distrito Federal (DF), Brazil, in dry, rainy, and winter crop seasons, in 2012, 2013, and 2014.

\begin{tabular}{|c|c|c|c|c|c|c|c|c|c|c|c|c|c|c|c|}
\hline \multirow[t]{2}{*}{$\begin{array}{l}\text { Environment }{ }^{(1)} \\
\text { (location/season/year) }\end{array}$} & \multicolumn{3}{|c|}{ Darkening } & \multicolumn{3}{|c|}{$\begin{array}{c}\text { Yield } \\
\left(\mathrm{kg} \mathrm{ha}^{-1}\right)\end{array}$} & \multicolumn{3}{|c|}{ Architecture } & \multicolumn{3}{|c|}{ Lodging } & \multicolumn{3}{|c|}{$\begin{array}{l}\text { 100-grain weight } \\
\text { (g) }\end{array}$} \\
\hline & Mean & $\mathrm{CV}^{(2)}$ & $\mathrm{SA}^{(3)}$ & Mean & $\mathrm{CV}$ & SA & Mean & $\mathrm{CV}$ & SA & Mean & $\mathrm{CV}$ & SA & Mean & $\mathrm{CV}$ & SA \\
\hline Brasília 1 in DF/winter/2012 & 2.9 & 12.7 & 0.88 & 2,866 & 17.0 & 0.79 & 4.7 & 9.6 & 0.77 & 4.5 & 15.7 & 0.78 & 24.0 & 3.8 & 0.89 \\
\hline Brasília 2 in DF/winter/2012 & 3.0 & 19.3 & 0.89 & 2,335 & 19.9 & 0.77 & 4.8 & 9.7 & 0.77 & 4.7 & 12.7 & 0.85 & 27.1 & 5.3 & 0.91 \\
\hline $\mathrm{SAG}$ in $\mathrm{GO} /$ winter/2012 & 2.9 & 17.6 & 0.80 & 5,303 & 13.9 & 0.74 & 5.2 & 9.6 & 0.75 & 5.2 & 12.4 & 0.67 & 24.4 & 3.9 & 0.84 \\
\hline Uberlândia in MG/dry/2013 & 2.4 & 12.1 & 0.90 & - & - & - & - & - & - & - & - & - & - & - & - \\
\hline Anápolis in GO/winter/2013 & 2.7 & 17.1 & 0.93 & 3,339 & 206 & 0.74 & 4.5 & 11.2 & 0.79 & 4.6 & 17.8 & 0.88 & 25.8 & 5.5 & 0.93 \\
\hline Cáceres MT/winter/2013 & 2.9 & 15.3 & 0.94 & 1,562 & 17.8 & 0.79 & 5.6 & 10.3 & 0.81 & - & - & - & 23.7 & 5.5 & 0.94 \\
\hline $\mathrm{SAG}$ in $\mathrm{GO} /$ winter/2013 & 3.0 & 14.5 & 0.94 & - & - & - & - & - & - & - & - & - & - & - & - \\
\hline Sete Lagoas in MG/winter/2013 & 2.6 & 15.7 & 0.92 & 4,722 & 10.9 & 0.67 & - & - & - & - & - & - & 22.8 & 5.1 & 0.92 \\
\hline Carira in SE/rainy /2013 & 4.2 & 9.8 & 0.93 & 2,314 & 13.6 & 0.80 & - & - & - & - & - & - & 23.2 & 3.8 & 0.92 \\
\hline BSF in PE/rainy/2013 & 2.8 & 16.0 & 0.91 & - & - & - & - & - & - & - & - & - & 24.7 & 5.2 & 0.91 \\
\hline Brasília in DF/rainy/2013 & 3.0 & 19.7 & 0.96 & 2,342 & 16.3 & 0.84 & 4.9 & 11.3 & 0.85 & 4.5 & 18.0 & 0.91 & 23.1 & 4.1 & 0.94 \\
\hline Ponta Grossa in PR/rainy/2013 & 3.6 & 15.1 & 0.96 & 3,631 & 14.5 & 0.89 & 5.0 & 8.9 & 0.86 & - & - & - & 22.3 & 5.1 & 0.95 \\
\hline SAG in GO/rainy /2013 & 3.4 & 20.7 & 0.94 & - & - & - & 5.7 & 11.4 & 0.81 & 5.2 & 11.3 & 0.89 & - & - & - \\
\hline Cáceres in MT/winter/2014 & 3.1 & 11.1 & 0.97 & 1,934 & 132 & 0.90 & - & - & - & - & - & - & 24.7 & 4.0 & 0.95 \\
\hline $\mathrm{SAG}$ in $\mathrm{GO} /$ winter/2014 & 3.3 & 17.3 & 0.97 & 2,579 & 13.7 & 0.86 & 5.6 & 13.8 & 0.92 & 5.5 & 13.6 & 0.91 & 22.1 & 5.7 & 0.96 \\
\hline
\end{tabular}

${ }^{(1)}$ SAG, Santo Antônio de Goiás; and BSF, Bélem de São Francisco. ${ }^{(2)}$ Coefficient of variation (\%). ${ }^{(3)}$ Selective acuracy. 
From the estimates of $Z_{\mathrm{i}}$ for seed-coat darkening, $64 \%$ of the lines had good adaptation $\left(Z_{i}>4.0\right)$. The CNFC 16709 and CNFC 16871 lines showed the highest estimates of $Z_{i}(5.2)$, higher than that found for BRSMG Madrepérola (Table 3). In general, the lines that had the best mean values were the most adapted.

Differences were also observed in the stability of the lines for seed-coat darkening. The stability of approximately $66 \%$ of the lines was considered to be good $\left(\mathrm{CV}_{\mathrm{i}}<15.0 \%\right)$. Twelve of these lines had $\mathrm{CV}_{\mathrm{i}} \leq 10.0 \%$, just as the BRSMG Madrepérola check cultivar (Table 3), showing that, even with environmental variations, their seed coats always have optimal coloring. Considering the mean, adaptability, and stability for seed-coat darkening, 12 lines were identified as superior, most notably CNFC 16871 $\left(\overline{\mathrm{x}}=1.9, \mathrm{Z}_{\mathrm{i}}=5.2\right.$, and $\left.\mathrm{CV}_{\mathrm{i}}=8.8 \%\right), \mathrm{CNFC} 16754(\overline{\mathrm{x}}=2.2$, $\mathrm{Z}_{\mathrm{i}}=4.8$, and $\left.\mathrm{CV}_{\mathrm{i}}=9.2 \%\right)$, and CNFC $16778(\overline{\mathrm{x}}=2.3$, $\mathrm{Z}_{\mathrm{i}}=4.8$, and $\mathrm{CV}_{\mathrm{i}}=8.1 \%$ ).
For grain yield, the cluster analysis formed four groups of mean values. The first group was composed of lines CNFC 16709, CNFC 16757, CNFC 16694, CNFC 16902, and CNFC 16876 and of cultivars BRS Estilo, BRS Notável, BRS Sublime, and BRSMG Madrepérola, with yields ranging from 3,303 to 3,474 $\mathrm{kg} \mathrm{ha}^{-1}$ (Table 3). The second group consisted of 15 lines, and the third group, of 12 lines and of cultivar BRS Cometa. Another 12 lines had lower yields than BRS Cometa, showing low potential for use as new cultivars.

Twenty lines (45\%) had good adaptability estimates for grain yield $\left(\mathrm{Z}_{\mathrm{i}}>4.0\right)$. Lines CNFC 16709, CNFC 16902, CNFC 16876, CNFC 16757, and CNFC 16694 had an adaptability similar to that of cultivars BRS Estilo, BRS Notável, BRS Sublime, and BRSMG Madrepérola (Table 3). In addition, along with the five check cultivars, $75 \%$ of the lines had good stability $\left(\mathrm{CV}_{\mathrm{i}}<25 \%\right)$. Considering the mean, adaptability, and stability for yield, 16 lines were identified as having

Table 2. Summary of the joint analyses of variance for seed-coat darkening, grain yield, plant architecture, resistance to lodging, and 100-grain weight of 49 common bean (Phaseolus vulgaris) genotypes evaluated in the states of Goiás, Sergipe, Pernambuco, Paraná, and Minas Gerais, as well as in Distrito Federal, Brazil, in the dry, rainy, and winter crop seasons, in 2012, 2013, and 2014.

\begin{tabular}{|c|c|c|c|c|c|c|c|c|c|c|c|c|c|c|c|}
\hline \multirow[t]{2}{*}{ Source of variation } & \multicolumn{3}{|c|}{ Darkening $^{(1)}$} & \multicolumn{3}{|c|}{ Yield $\left(\mathrm{kg} \mathrm{ha}^{-1}\right)$} & \multicolumn{3}{|c|}{ Architecture } & \multicolumn{3}{|c|}{ Lodging } & \multicolumn{3}{|c|}{ 100-grain weight (g) } \\
\hline & DF & MS & $\mathrm{p}$ & DF & MS & $\mathrm{p}$ & DF & MS & $\mathrm{p}$ & $\mathrm{DF}$ & MS & $\mathrm{p}$ & $\mathrm{DF}$ & MS & $\mathrm{p}$ \\
\hline Block/locations & 30 & 1.0 & - & 22 & 1842297 & - & 18 & 1.2 & - & 14 & 1.9 & - & 24 & 23.5 & - \\
\hline Environment (E) & 14 & 60.5 & $<0.01$ & 10 & 198885205 & $<0.01$ & 8 & 26.4 & $<0.01$ & 6 & 39.4 & $<0.01$ & 11 & 617.3 & $<0.01$ \\
\hline Genotypes (G) & 48 & 18.4 & $<0.01$ & 48 & 2176829 & $<0.01$ & 48 & 4.6 & $<0.01$ & 48 & 11.5 & $<0.01$ & 48 & 91.0 & $<0.01$ \\
\hline Line $(\mathrm{L})$ & 43 & 7.6 & $<0.01$ & 43 & 1898512 & $<0.01$ & 43 & 3.3 & $<0.01$ & 43 & 8.8 & $<0.01$ & 43 & 97.9 & $<0.01$ \\
\hline L/population $1^{(2)}$ & 10 & 9.3 & $<0.01$ & 10 & 2566162 & $<0.01$ & 10 & 7.4 & $<0.01$ & 10 & 12.1 & $<0.01$ & 10 & 114.1 & $<0.01$ \\
\hline $\mathrm{L} /$ population $2^{(3)}$ & 10 & 4.4 & $<0.01$ & 10 & 976497 & $<0.01$ & 10 & 2.0 & $<0.01$ & 10 & 6.0 & $<0.01$ & 10 & 100.8 & $<0.01$ \\
\hline L/population $3^{(4)}$ & 10 & 7.2 & $<0.01$ & 10 & 1098064 & $<0.01$ & 10 & 1.8 & $<0.01$ & 10 & 10.3 & $<0.01$ & 10 & 77.4 & $<0.01$ \\
\hline $\mathrm{L} /$ population $4^{(5)}$ & 10 & 6.2 & $<0.01$ & 10 & 2798978 & $<0.01$ & 10 & 1.9 & $<0.01$ & 10 & 5.1 & $<0.01$ & 10 & 52.6 & $<0.01$ \\
\hline Contrast & 3 & 19.1 & $<0.01$ & 3 & 2413007 & $<0.01$ & 3 & 3.5 & $<0.01$ & 3 & 13.7 & $<0.01$ & 3 & 253.4 & $<0.01$ \\
\hline Parents (P) & 4 & 58.0 & $<0.01$ & 4 & 1267377 & 0.05 & 4 & 10.4 & $<0.01$ & 4 & 25.0 & $<0.01$ & 4 & 25.2 & $<0.01$ \\
\hline L vs $\mathrm{P}$ & 1 & 322.0 & $<0.01$ & 1 & 17782276 & $<0.01$ & 1 & 36.8 & $<0.01$ & 1 & 73.2 & $<0.01$ & 1 & 59.2 & $<0.01$ \\
\hline $\mathrm{G} \times \mathrm{E}$ & 672 & 0.6 & $<0.01$ & 480 & 636521 & $<0.01$ & 384 & 0.8 & $<0.01$ & 288 & 2.0 & $<0.01$ & 528 & 4.3 & $<0.01$ \\
\hline $\mathrm{L} \times \mathrm{E}$ & 602 & 0.6 & $<0.01$ & 430 & 611350 & $<0.01$ & 344 & 0.7 & $<0.01$ & 258 & 2.0 & $<0.01$ & 473 & 4.4 & $<0.01$ \\
\hline $\mathrm{L} /$ population $1 \times \mathrm{E}$ & 140 & 0.6 & $<0.01$ & 100 & 528017 & $<0.01$ & 80 & 0.7 & $<0.01$ & 60 & 1.8 & $<0.01$ & 110 & 3.5 & $<0.01$ \\
\hline $\mathrm{L} /$ population $2 \times \mathrm{E}$ & 140 & 0.5 & $<0.01$ & 100 & 431121 & $<0.01$ & 80 & 0.6 & 0.02 & 60 & 1.5 & $<0.01$ & 110 & 4.0 & $<0.01$ \\
\hline L/population $3 \times \mathrm{E}$ & 140 & 0.5 & $<0.01$ & 100 & 682532 & $<0.01$ & 80 & 0.4 & 4.69 & 60 & 3.2 & $<0.01$ & 110 & 3.2 & $<0.01$ \\
\hline L/population $4 \times \mathrm{E}$ & 140 & 0.5 & $<0.01$ & 100 & 719078 & $<0.01$ & 80 & 0.8 & $<0.01$ & 60 & 1.3 & $<0.01$ & 110 & 5.0 & $<0.01$ \\
\hline Contrast $\times \mathrm{E}$ & 42 & 1.0 & $<0.01$ & 30 & 893530 & $<0.01$ & 24 & 1.2 & $<0.01$ & 18 & 2.0 & $<0.01$ & 33 & 10.6 & $<0.01$ \\
\hline $\mathrm{P} \times \mathrm{E}$ & 56 & 0.4 & 0.02 & 40 & 479709 & 0.05 & 32 & 1.3 & $<0.01$ & 24 & 1.9 & $<0.01$ & 44 & 3.0 & $<0.01$ \\
\hline$(\mathrm{L}$ vs $\mathrm{P}) \times \mathrm{E}$ & 14 & 1.5 & $<0.01$ & 10 & 2346121 & $<0.01$ & 8 & 3.7 & $<0.01$ & 6 & 4.1 & $<0.01$ & 11 & 3.9 & 0.16 \\
\hline Error & 1,440 & 0.2 & - & 1,056 & 248557 & - & 864 & 0.3 & - & 672 & 0.6 & - & 1,152 & 1.4 & - \\
\hline
\end{tabular}

${ }^{(1)} \mathrm{DF}$, degrees of freedom; MS, mean square; and p, probability (\%). (2)'BRSMG Madrepérola' $\times$ 'BRS Sublime'. (3)'BRSMG Madrepérola' × 'BRS Cometa'. (4)'BRSMG Madrepérola' × 'BRS Estilo'. (5)'BRSMG Madrepérola' × 'BRS Notável'. 
Table 3. Estimates of mean values and of adaptability $\left(\mathrm{Z}_{\mathrm{i}}\right)$ and stability $\left(\mathrm{CV}_{\mathrm{i}}\right)$ parameters, obtained by the method of Nunes et al. (2005), for seed-coat darkening, yield, plant architecture, resistance to lodging, and 100-grain weight of 49 lines and five check cultivars of common bean (Phaseolus vulgaris), evaluated in different environments in the states of Goiás, Sergipe, Pernambuco, Paraná, and Minas Gerais, as well as in Distrito Federal, Brazil, in the dry, rainy, and winter crop seasons, in 2012, 2013, and 2014.

\begin{tabular}{|c|c|c|c|c|c|c|c|c|c|c|c|c|c|c|c|}
\hline \multirow[t]{2}{*}{ Line or cultivar } & \multicolumn{3}{|c|}{ Darkening } & \multicolumn{3}{|c|}{ Yield $\left(\mathrm{kg} \mathrm{ha}^{-1}\right)$} & \multicolumn{3}{|c|}{ Architecture } & \multicolumn{3}{|c|}{ Lodging } & \multicolumn{3}{|c|}{ 100-grain weight (g) } \\
\hline & $\mathrm{X}^{(1)}$ & $Z_{i}^{(2)}$ & $\mathrm{CV}_{\mathrm{i}}^{(3)}$ & $\mathrm{X}^{(1)}$ & $\mathrm{Z}_{\mathrm{i}}$ & $\mathrm{CV}_{\mathrm{i}}$ & $\mathrm{X}^{(1)}$ & $\mathrm{Z}_{\mathrm{i}}$ & $\mathrm{CV}_{\mathrm{i}}$ & $\mathrm{X}^{(1)}$ & $Z_{i}^{(2)}$ & $\mathrm{CV}_{\mathrm{i}}^{(3)}$ & $\mathrm{X}^{(1)}$ & $\mathrm{Z}_{\mathrm{i}}$ & $\mathrm{CV}_{\mathrm{i}}$ \\
\hline CNFC 16871 & $1.9 \mathrm{a}$ & 5.2 & 8.8 & $3,041 \mathrm{~b}$ & 4.2 & 35.6 & $4.9 \mathrm{~b}$ & 4.1 & 12.9 & $4.9 \mathrm{~d}$ & 3.9 & 18.7 & $23.0 \mathrm{e}$ & 3.8 & 17.9 \\
\hline CNFC 16709 & $1.9 \mathrm{a}$ & 5.2 & 11.2 & $3,474 \mathrm{a}$ & 4.9 & 15.2 & $5.1 \mathrm{c}$ & 3.8 & 26.1 & $5.2 \mathrm{~d}$ & 4.2 & 24.8 & $23.8 \mathrm{~d}$ & 4.1 & 12.4 \\
\hline BRSMG Madrepérola & $2.1 \mathrm{a}$ & 5.0 & 10.0 & $3,303 a$ & 4.5 & 17.4 & $5.6 \mathrm{~d}$ & 3.1 & 26.8 & $6.2 \mathrm{f}$ & 2.7 & 16.9 & $24.0 \mathrm{~d}$ & 4.2 & 12.7 \\
\hline CNFC 16697 & $2.1 \mathrm{~b}$ & 4.9 & 12.6 & $3,161 b$ & 4.4 & 14.3 & $5.9 \mathrm{e}$ & 2.5 & 33.4 & $5.9 \mathrm{f}$ & 3.1 & 23.5 & $25.5 b$ & 5.3 & 16.2 \\
\hline CNFC 16754 & $2.2 \mathrm{~b}$ & 4.8 & 9.2 & $3,140 \mathrm{~b}$ & 4.4 & 18.2 & $5.1 \mathrm{c}$ & 3.8 & 15.3 & $5.2 \mathrm{~d}$ & 3.9 & 10.5 & $24.0 \mathrm{~d}$ & 4.2 & 9.1 \\
\hline CNFC 16778 & $2.3 b$ & 4.8 & 8.1 & $3,027 b$ & 4.2 & 26.6 & $5.2 \mathrm{c}$ & 3.7 & 12.8 & $5.8 \mathrm{f}$ & 3.3 & 9.6 & $23.3 \mathrm{e}$ & 3.7 & 11.7 \\
\hline CNFC 16772 & $2.3 \mathrm{c}$ & 4.7 & 15.6 & $3,115 b$ & 4.3 & 24.1 & $5.2 \mathrm{c}$ & 3.7 & 26.2 & $6.8 \mathrm{~h}$ & 3.3 & 18.7 & $23.1 \mathrm{e}$ & 3.7 & 22.3 \\
\hline CNFC 16757 & $2.3 \mathrm{c}$ & 4.6 & 21.0 & $3,289 \mathrm{a}$ & 4.6 & 13.4 & $5.2 \mathrm{c}$ & 3.7 & 14.6 & $5.4 \mathrm{e}$ & 3.4 & 31.9 & $23.2 \mathrm{e}$ & 3.8 & 13.9 \\
\hline CNFC 16729 & $2.4 \mathrm{c}$ & 4.6 & 10.2 & $2,898 \mathrm{c}$ & 3.8 & 17.4 & $5.5 \mathrm{~d}$ & 3.2 & 22.6 & $5.9 f$ & 2.8 & 16.8 & $24.7 \mathrm{c}$ & 4.7 & 12.0 \\
\hline CNFC 16866 & $2.4 \mathrm{c}$ & 4.6 & 11.4 & $2,982 \mathrm{c}$ & 4.0 & 20.5 & $5.1 \mathrm{c}$ & 3.9 & 14.5 & $5.2 \mathrm{~d}$ & 3.8 & 11.7 & $22.7 f$ & 3.8 & 14.3 \\
\hline CNFC 16763 & $2.4 \mathrm{c}$ & 4.6 & 8.3 & $2,698 \mathrm{~d}$ & 3.4 & 23.2 & $5.0 \mathrm{c}$ & 3.9 & 11.6 & $5.0 \mathrm{~d}$ & 3.7 & 18.7 & $21.2 \mathrm{~h}$ & 2.9 & 20.1 \\
\hline CNFC 16726 & $2.4 \mathrm{c}$ & 4.6 & 13.2 & $2,649 \mathrm{~d}$ & 3.3 & 22.3 & $4.7 b$ & 4.4 & 13.3 & $4.1 b$ & 4.7 & 12.0 & $20.7 \mathrm{i}$ & 2.5 & 24.8 \\
\hline CNFC 16838 & $2.5 \mathrm{c}$ & 4.5 & 9.7 & $2,927 \mathrm{c}$ & 3.8 & 17.3 & $5.1 \mathrm{c}$ & 3.9 & 30.3 & $5.7 f$ & 3.4 & 16.3 & $23.8 \mathrm{~d}$ & 4.2 & 13.9 \\
\hline CNFC 16702 & $2.5 \mathrm{~d}$ & 4.4 & 10.2 & $3,025 \mathrm{~b}$ & 4.1 & 18.1 & $5.5 \mathrm{~d}$ & 3.2 & 33.7 & $5.5 \mathrm{e}$ & 3.8 & 21.5 & $21.1 \mathrm{~h}$ & 2.8 & 20.1 \\
\hline CNFC 16775 & $2.5 \mathrm{~d}$ & 4.4 & 9.4 & $3,100 \mathrm{~b}$ & 4.2 & 22.2 & $5.5 \mathrm{~d}$ & 3.1 & 21.9 & $5.4 \mathrm{e}$ & 3.7 & 18.8 & $23.2 \mathrm{e}$ & 3.9 & 14.3 \\
\hline CNFC 16690 & $2.5 \mathrm{~d}$ & 4.4 & 16.4 & $2,953 \mathrm{c}$ & 3.7 & 27.2 & $4.9 \mathrm{~b}$ & 4.1 & 24.0 & $5.0 \mathrm{~d}$ & 3.9 & 24.4 & $22.0 \mathrm{~g}$ & 3.2 & 14.9 \\
\hline CNFC 16747 & $2.5 \mathrm{~d}$ & 4.4 & 12.4 & $2,820 \mathrm{c}$ & 3.7 & 25.6 & $4.8 \mathrm{~b}$ & 4.3 & 18.3 & $3.9 \mathrm{a}$ & 5.2 & 11.3 & $21.8 \mathrm{~g}$ & 3.3 & 14.0 \\
\hline CNFC 16857 & $2.5 \mathrm{~d}$ & 4.4 & 10.0 & $2,688 \mathrm{~d}$ & 3.4 & 38.2 & $4.7 b$ & 4.5 & 20.9 & $4.3 b$ & 4.7 & 15.4 & $23.1 \mathrm{e}$ & 3.7 & 16.6 \\
\hline CNFC 16694 & $2.6 \mathrm{~d}$ & 4.3 & 9.7 & $3,272 \mathrm{a}$ & 4.5 & 23.6 & $4.7 b$ & 4.5 & 14.0 & $4.2 b$ & 4.8 & 12.1 & $21.9 \mathrm{~g}$ & 3.2 & 13.9 \\
\hline CNFC 16741 & $2.6 \mathrm{~d}$ & 4.4 & 6.6 & $3,020 \mathrm{~b}$ & 4.2 & 27.6 & $5.2 \mathrm{c}$ & 3.7 & 14.1 & $5.5 \mathrm{e}$ & 3.5 & 20.2 & $23.4 \mathrm{e}$ & 3.9 & 13.3 \\
\hline CNFC 16902 & $2.6 \mathrm{~d}$ & 4.3 & 11.8 & $3,409 \mathrm{a}$ & 4.9 & 23.0 & $5.3 \mathrm{c}$ & 3.5 & 16.0 & $5.6 \mathrm{e}$ & 3.4 & 11.7 & $24.6 \mathrm{c}$ & 4.8 & 18.9 \\
\hline CNFC 16761 & $2.6 \mathrm{~d}$ & 4.4 & 11.6 & $2,756 \mathrm{~d}$ & 3.5 & 22.5 & $4.6 b$ & 4.7 & 13.0 & $4.7 \mathrm{c}$ & 4.3 & 19.0 & $20.6 \mathrm{i}$ & 2.6 & 23.2 \\
\hline CNFC 16831 & $2.6 \mathrm{~d}$ & 4.3 & 14.0 & $2,769 d$ & 3.5 & 8.3 & $4.3 \mathrm{a}$ & 5.3 & 12.8 & $3.5 \mathrm{a}$ & 5.4 & 12.2 & $25.3 b$ & 5.0 & 7.0 \\
\hline CNFC 16872 & $2.6 \mathrm{~d}$ & 4.3 & 9.1 & $3,222 b$ & 4.5 & 20.6 & $5.5 \mathrm{~d}$ & 3.1 & 24.4 & $5.4 \mathrm{e}$ & 3.5 & 19.6 & $24.0 \mathrm{~d}$ & 4.5 & 15.6 \\
\hline CNFC 16788 & $2.6 \mathrm{~d}$ & 4.3 & 9.5 & $3,153 b$ & 4.4 & 20.0 & $5.4 \mathrm{~d}$ & 3.3 & 19.4 & $5.4 \mathrm{e}$ & 3.7 & 22.7 & $23.0 \mathrm{e}$ & 3.8 & 16.1 \\
\hline CNFC 16713 & $2.6 \mathrm{~d}$ & 4.3 & 8.2 & $2,596 \mathrm{~d}$ & 3.2 & 27.8 & $4.4 \mathrm{a}$ & 4.9 & 13.7 & $4.2 \mathrm{~b}$ & 5.1 & 10.8 & $20.8 \mathrm{i}$ & 2.5 & 21.6 \\
\hline CNFC 16820 & $2.8 \mathrm{e}$ & 4.1 & 12.1 & $2,932 \mathrm{c}$ & 3.9 & 21.5 & $4.7 b$ & 4.4 & 11.5 & $4.8 \mathrm{~d}$ & 4.5 & 14.8 & $22.9 \mathrm{e}$ & 3.6 & 12.9 \\
\hline CNFC 16843 & $2.8 \mathrm{e}$ & 4.1 & 12.0 & $2,805 \mathrm{c}$ & 3.6 & 20.2 & $5.2 \mathrm{c}$ & 3.6 & 22.8 & $5.2 \mathrm{~d}$ & 3.9 & 31.8 & $22.2 f$ & 3.4 & 19.0 \\
\hline CNFC 16862 & $2.8 \mathrm{e}$ & 4.1 & 12.6 & $3,220 \mathrm{~b}$ & 4.5 & 12.1 & $4.9 \mathrm{~b}$ & 4.2 & 23.0 & $5.0 \mathrm{~d}$ & 3.9 & 21.3 & $21.3 \mathrm{~h}$ & 3.0 & 24.4 \\
\hline CNFC 16724 & $2.8 \mathrm{e}$ & 4.0 & 17.7 & $3,102 b$ & 4.1 & 20.5 & $4.5 \mathrm{a}$ & 4.8 & 17.1 & $4.7 \mathrm{c}$ & 4.4 & 14.0 & $21.8 \mathrm{~g}$ & 3.0 & 14.2 \\
\hline CNFC 16881 & $2.8 \mathrm{e}$ & 4.0 & 18.5 & $2,723 \mathrm{~d}$ & 3.5 & 24.7 & $5.4 \mathrm{c}$ & 3.6 & 26.9 & $5.9 \mathrm{f}$ & 3.2 & 25.0 & $23.3 \mathrm{e}$ & 4.0 & 11.5 \\
\hline CNFC 16827 & $2.9 \mathrm{e}$ & 4.0 & 11.4 & $2,602 d$ & 3.2 & 21.5 & $5.1 \mathrm{c}$ & 3.8 & 13.6 & $5.6 \mathrm{e}$ & 3.5 & 22.6 & $22.5 \mathrm{f}$ & 3.4 & 16.0 \\
\hline CNFC 16876 & $2.9 \mathrm{e}$ & 3.8 & 10.1 & $3,305 \mathrm{a}$ & 4.7 & 17.3 & $5.3 \mathrm{c}$ & 3.5 & 27.9 & $5.2 \mathrm{~d}$ & 3.7 & 15.5 & $23.5 \mathrm{e}$ & 4.1 & 17.6 \\
\hline CNFC 16877 & $3.0 \mathrm{e}$ & 3.8 & 18.2 & $2,898 \mathrm{c}$ & 3.8 & 16.5 & $4.9 \mathrm{~b}$ & 4.2 & 13.4 & $5.5 \mathrm{e}$ & 3.5 & 11.2 & $24.4 \mathrm{c}$ & 4.5 & 11.3 \\
\hline CNFC 16692 & $3.1 \mathrm{f}$ & 3.6 & 16.8 & $2,646 \mathrm{~d}$ & 3.2 & 34.7 & $5.8 \mathrm{e}$ & 2.6 & 31.5 & $6.4 \mathrm{~g}$ & 2.3 & 26.6 & $22.3 f$ & 3.3 & 14.7 \\
\hline CNFC 16826 & $3.1 \mathrm{f}$ & 3.6 & 13.6 & $2,590 \mathrm{~d}$ & 3.2 & 23.5 & $4.9 \mathrm{~b}$ & 4.1 & 16.5 & $5.1 \mathrm{~d}$ & 4.3 & 11.0 & $23.1 \mathrm{e}$ & 3.7 & 19.1 \\
\hline CNFC 16793 & $3.1 \mathrm{f}$ & 3.7 & 17.4 & $2,943 \mathrm{c}$ & 3.9 & 17.3 & $5 \mathrm{c}$ & 4.1 & 13.4 & $5.0 \mathrm{~d}$ & 4.3 & 17.9 & $26.0 \mathrm{a}$ & 5.3 & 11.5 \\
\hline CNFC 16852 & $3.1 \mathrm{f}$ & 3.6 & 14.2 & $2,448 \mathrm{~d}$ & 2.8 & 28.1 & $5.1 \mathrm{c}$ & 3.9 & 23.2 & $5.9 \mathrm{f}$ & 3.0 & 15.4 & $23.5 \mathrm{e}$ & 3.9 & 20.8 \\
\hline CNFC 16832 & $3.2 \mathrm{f}$ & 3.5 & 17.5 & $2,847 \mathrm{c}$ & 3.7 & 22.7 & $4.9 \mathrm{~b}$ & 4.3 & 18.1 & $4.4 \mathrm{~b}$ & 4.6 & 18.0 & $26.2 \mathrm{a}$ & 5.4 & 11.8 \\
\hline CNFC 16849 & $3.2 \mathrm{f}$ & 3.5 & 18.7 & $2,986 \mathrm{c}$ & 3.9 & 24.9 & $4.8 \mathrm{~b}$ & 4.3 & 17.0 & $4.9 \mathrm{~d}$ & 4.1 & 10.4 & $25.9 \mathrm{a}$ & 5.2 & 12.3 \\
\hline CNFC 16830 & $3.2 \mathrm{f}$ & 3.5 & 21.5 & $2,886 \mathrm{c}$ & 3.8 & 26.0 & $5.1 \mathrm{c}$ & 3.7 & 26.8 & $4.8 \mathrm{~d}$ & 4.3 & 14.3 & $25.7 \mathrm{~b}$ & 5.2 & 13.6 \\
\hline CNFC 16819 & $3.3 \mathrm{~g}$ & 3.4 & 16.7 & $2,710 \mathrm{~d}$ & 3.4 & 15.0 & $4.6 \mathrm{~b}$ & 4.5 & 14.4 & $4.7 \mathrm{c}$ & 4.4 & 20.8 & $24.0 \mathrm{~d}$ & 4.2 & 14.8 \\
\hline CNFC 16846 & $3.4 \mathrm{~g}$ & 3.3 & 19.8 & $3,193 b$ & 4.3 & 19.1 & $4.9 b$ & 4.2 & 13.8 & $5.0 \mathrm{~d}$ & 4.2 & 16.9 & $26.4 \mathrm{a}$ & 5.6 & 8.7 \\
\hline CNFC 16722 & $3.6 \mathrm{~h}$ & 3.0 & 28.4 & $3,136 \mathrm{~b}$ & 4.2 & 21.6 & $4.9 b$ & 4.0 & 21.3 & $4.8 \mathrm{~d}$ & 4.0 & 22.7 & $24.0 \mathrm{~d}$ & 4.1 & 14.4 \\
\hline CNFC 16760 & $3.7 \mathrm{~h}$ & 2.9 & 17.6 & $3,006 \mathrm{~b}$ & 4.1 & 34.9 & $5.2 \mathrm{c}$ & 3.6 & 15.7 & $5.4 \mathrm{e}$ & 3.6 & 12.9 & $26.3 \mathrm{a}$ & 5.5 & 10.3 \\
\hline BRS Sublime & $4.1 \mathrm{i}$ & 2.4 & 17.7 & $3,337 \mathrm{a}$ & 4.8 & 16.0 & $4.3 \mathrm{a}$ & 5.1 & 24.1 & $3.8 \mathrm{a}$ & 5.3 & 13.7 & $24.2 \mathrm{c}$ & 4.4 & 14.2 \\
\hline BRS Estilo & $4.1 \mathrm{i}$ & 2.4 & 25.1 & $3,499 \mathrm{a}$ & 5.0 & 9.3 & $4.2 \mathrm{a}$ & 5.2 & 20.7 & $3.9 \mathrm{a}$ & 5.1 & 19.8 & $25.5 b$ & 5.0 & 8.4 \\
\hline BRS Notável & $4.8 \mathrm{j}$ & 1.5 & 42.4 & $3,403 a$ & 4.9 & 22.0 & $4.2 \mathrm{a}$ & 5.3 & 23.4 & $3.7 \mathrm{a}$ & 5.5 & 17.4 & $23.7 \mathrm{~d}$ & 4.2 & 12.4 \\
\hline BRS Cometa & $4.9 \mathrm{j}$ & 1.4 & 49.6 & $2,980 \mathrm{c}$ & 4.0 & 16.3 & $4.3 \mathrm{a}$ & 5.1 & 17.2 & $3.7 \mathrm{a}$ & 5.2 & 13.2 & $23.0 \mathrm{e}$ & 3.7 & 15.2 \\
\hline
\end{tabular}

${ }^{(1)}$ Means followed by equal letters do not differ by the test of Scott-Knott, at $10 \%$ probability. ${ }^{(2)}$ Parameter of adaptability by the method of Nunes et al. (2005). ${ }^{(3)}$ Coefficient of variation of the variable standardized for each genotype, considered the parameter of stability by the method of Nunes et al. (2005). 
mean values higher than $3,025 \mathrm{~kg} \mathrm{ha}^{-1}, \mathrm{Z}_{\mathrm{i}}$ greater than 4, and $\mathrm{CV}_{\mathrm{i}}$ lower than 25\%; CNFC 16709, CNFC 16757, CNFC 16876, CNFC 16902, and CNFC 16694 stood out.

Five groups of means were formed for plant architecture. The first was composed of cultivars BRS Estilo, BRS Notável, BRS Cometa, and BRS Sublime (Table 3), which clearly have upright plants (Alvares et al., 2016; Silva et al., 2018), and of lines CNFC 16831, CNFC 16713, and CNFC 16724; these lines had scores from 4.2 to 4.5 and were the most upright plants. The second and third groups consisted of 16 and 18 lines, respectively, which did not have an ideal plant architecture, but showed more upright than BRSMG Madrepérola, classified in the fourth group of mean values, with scores from 5.4 to 5.6. Therefore, $84 \%$ of the lines were more upright than BRSMG Madrepérola, confirming once more the effectiveness of the selection made by Alvares et al. (2016) and that it is also possible to obtain lines with more upright plants. Furthermore, in terms of plant architecture, 19 lines $(43 \%)$ had good adaptability $\left(Z_{i}>4.0\right)$. Line CNFC 16831 had better adaptability $\left(Z_{\mathrm{i}}=5.3\right)$, together with cultivars BRS Notável, BRS Estilo, BRS Cometa, and BRS Sublime. Moreover, $61 \%$ of the lines had good stability $\left(\mathrm{CV}_{\mathrm{i}}<20 \%\right)$. Among the 15 lines that showed the best means, adaptability, and stability for upright plant architecture the most noteworthy were CNFC 16831, CNFC 16713, and CNFC 16724.

Resistance to lodging was greater in $82 \%$ of the lines, compared with cultivar BRSMG Madrepérola (Table 3). CNFC 16831 and CNFC 16747 stood out for having a performance similar to that of the check cultivars with lower lodging, i.e., BRS Cometa, BRS Notável, BRS Sublime, and BRS Estilo. Seventeen lines (39\%) had good adaptability, and, among them, the same two lines stood out again. In addition, $68 \%$ of the lines had good stability $\left(\mathrm{CV}_{\mathrm{i}}<20 \%\right)$. Twenty-one lines combined good mean values, high adaptability, and high stability for resistance to lodging, and the most noteworthy were CNFC 16831, CNFC 16747, and CNFC 16726.

For 100-grain weight, CNFC 16846, CNFC 16760, CNFC 16832, CNFC 16793, and CNFC 16849 were in the group with the highest mean values, from 25.9 to $26.4 \mathrm{~g}$, which were considered even superior to those of the check cultivars (Table 3) (Pereira et al., 2017a; Arns et al., 2018). The second group consisted of another three lines, together with cultivar BRS Estilo, with mean values ranging from 25.3 to 25.7. The third group was composed of the BRS Sublime cultivar, together with three other lines, with mean values ranging from 24.2 to 24.7. Cultivars BRS Estilo and BRS Sublime are standards in the market as they have an 100-grain weight higher than $24 \mathrm{~g}$. Therefore, $25 \%$ of the lines have an optimal-sized bean grain.

Eighteen lines (41\%) showed an adaptability higher than the mean for 100-grain weight. Eight lines had high adaptability, with $Z_{i}$ estimates greater than or equal to that of BRS Estilo (Table 3). Twenty-six lines (59\%) presented estimates of $\mathrm{CV}_{\mathrm{i}}$ lower than $15 \%$, indicating high stability. Eleven lines combined high means, adaptability, and stability for 100-grain weight, with CNFC 16760, CNFC 16832, and CNFC 16793 being highlighted.

The identification of promising common bean lines to obtain new cultivars is a huge challenge, since lines must combine various phenotypes of agronomic interest and with grain quality, so that they have potential of becoming cultivars. Superiority for one or even a few traits is not enough. In the common bean production chain, the consumer is more and more demanding in regard to product quality, and the producer aims at greater profit from production (Pereira et al., 2017b). Therefore, it is necessary to select lines that combine desirable phenotypes in relation to the commercial quality of the grain, such as slow seed-coat darkening and 100-grain weight, as well as agronomic quality, including high yield, upright plants, and resistance to lodging. Besides traits of interest for the market, lines must show stability and be adapted to various environments. A wide adaptation favors a greater use of the cultivars in different regions and growing conditions, which is interesting for Brazil, where the public sector is the main responsible for supplying the market due to the low use of certified seeds.

The results of selection for each isolated trait show a large number of lines that have good mean values, high adaptability, and high stability for each trait: 27 lines (61\%) for slow seed-coat darkening, 16 lines (37\%) for high yield, 15 lines (34\%) for upright plants, 20 lines (45\%) for resistance to lodging, and 14 lines (32\%) for high 100-grain weight. However, the number of lines with desirable phenotypes for the traits simultaneously is much smaller, which was expected and has been reported in other studies (Alvares et al., 2016; Silva et al., 2018; Di Prado et al., 2019). 
Considering simultaneous selection for the five evaluated traits, eight lines were identified as superior, originating from four populations (crosses between the cultivars in parentheses): CNFC 16694 and CNFC 16709 (BRSMG Madrepérola x BRS Sublime); CNFC 16754 (BRSMG Madrepérola x BRS Estilo); CNFC 16820 and CNFC 16843 (BRSMG Madrepérola $\mathrm{x}$ BRS Cometa); and CNFC 16862, CNFC 16866, and
CNFC 16876 (BRSMG Madrepérola x BRS Notável) (Table 3). Among these eight lines, CNFC 16754 and CNFC 16820 stood out (Figure 1), showing the greatest potential to be recommended as new cultivars with slow seed-coat darkening and more upright plants. However, these lines should be evaluated in trials in multiple environments to verify their true potential for recommendation as new cultivars.

\begin{tabular}{|c|c|c|c|c|}
\hline Darkening & Grain yield & Architecture & Lodging & 100 grain weight \\
\hline \multicolumn{5}{|c|}{ CNFC 16754} \\
\hline & ${ }_{15}^{\mathrm{A} 15}$ & -A & & (112) \\
\hline \multicolumn{5}{|c|}{ CNFC 16820} \\
\hline & & & & A11 \\
\hline \multicolumn{5}{|c|}{ 'BRSMG Madrepérola' } \\
\hline & & A11 & & A10 \\
\hline \multicolumn{5}{|c|}{ 'BRS Notável' } \\
\hline & A1 & $\mathrm{A} 11$ & & A14 \\
\hline
\end{tabular}

Figure 1. Graph representation of the performance of lines, with the best mean values for seed-coat darkening, yield $\left(\mathrm{kg} \mathrm{ha}^{-1}\right)$, plant architecture, lodging, and 100-grain weight $(\mathrm{g})$, and of two check cultivars of common bean (Phaseolus vulgaris), using the graph method of Nunes et al. (2005). The value of the constant associated with variable $Z_{i}$ equal to 4 , represented by the lines in gray, and the axis refer to the different environments evaluated in Brazil: A1, Brasília, in Distrito Federal, in the winter crop season of 2012; A2, Brasília, in Distrito Federal, in the winter crop season of 2012; A3, Santo Antônio de Goiás, in the state of Goiás, in the winter crop season of 2012; A4, Uberlândia, in the state of Minas Gerais, in the dry crop season of 2013; A5, Anápolis, in the state of Goiás, in the winter crop season of 2013; A6, Cáceres, in the state of Mato Grosso, in the winter crop season of 2013; A7, Santo Antônio de Goiás, in the state of Goiás, in the winter crop season of 2013; A8, Sete Lagoas, in the state of Minas Gerais, in the winter crop season of 2013; A9, Carira, in the state of Sergipe, in the rainy crop season of 2013; A10, Belém de São Francisco, in the state of Pernambuco, in the rainy crop season of 2013; A11, Brasília, in Distrito Federal, in the rainy crop season of 2013; A12, Ponta Grossa, in the state of Paraná, in the rainy crop season of 2013; A13, Santo Antônio de Goiás, in the state of Goiás, in the rainy crop season of 2013; A14, Cáceres, in the state of Mato Grosso, in the winter crop season of 2014; and A15, Santo Antônio de Goiás, in the state of Goiás, in the winter crop season of 2014. 


\section{Conclusions}

1. Genotype by environment interaction is important for seed-coat darkening, yield, 100-grain weight, plant architecture, and resistance to lodging of common bean (Phaseolus vulgaris).

2. Lines CNFC 16754 and CNFC 16820 present slow seed-coat darkening, high yield and 100-grain weight, more upright plant architecture, and greater resistance to lodging, as well as high adaptability and stability for these traits in different combinations of locations, crop seasons, and years, showing their potential for recommendation as new cultivars and confirming that it is possible to join desirable phenotypes for the five studied traits.

\section{Acknowledgments}

To Conselho Nacional de Desenvolvimento Científico e Tecnológico (CNPq) and to Empresa Brasileira de Pesquisa Agropecuária (Embrapa), for financial support (CNPq process number 479331/2011-1 and Embrapa project 02.14.01.003.00.000); and to $\mathrm{CNPq}$, for research productivity scholarships granted (process numbers 313274/2019-3, 315043/2018-0, and 310604/2019-2), and to Fundação de Amparo à Pesquisa do Estado de Goiás (Fapeg), for doctoral scholarship granted and to Coordenação de Aperfeiçoamento de Pessoal Nível Superior (Capes), for master scholarship granted (Finance Code 001).

\section{References}

ALVARES, R.C.; PEREIRA, H.S.; MELO, L.C.; MIKLAS, P.N.; MELO, P.G.S. Induction of seed coat darkening in common beans (Phaseolus vulgaris L.) and the association with cooking time after storage. Australian Journal of Crop Science, v.14, p.21-27, 2020. DOI: https://doi.org/10.21475/ajcs.20.14.01.p1500.

ALVARES, R.C.; SILVA, F.C.; MELO, L.C.; MELO, P.G.S.; PEREIRA, H.S. Estimation of genetic parameters and selection of high-yielding, upright common bean lines with slow seedcoat darkening. Genetics and Molecular Research, v.15, gmr15049081, 2016. DOI: https://doi.org/10.4238/gmr15049081.

ALVARES, R.C.; STONEHOUSE, R.; SOUZA, T.L.P.O.; MELO, P.G.S.; MIKLAS, P.N.; BETT, K.E.; MELO, L.C.; RODRIGUES, L.A.; SOUZA, L.L.; PEREIRA, H.S. Generation and validation of genetic markers for the selection of carioca dry bean genotypes with the slow-darkening seed coat trait. Euphytica, v.215, art.141, 2019. DOI: https://doi.org/10.1007/s10681-019-2461-y.

ARNS, F.D.; RIBEIRO, N.D.; MEZZOMO, H.C.; STECKLING, S. de M.; KLÄSENER, G.R.; CASAGRANDE, C.R. Combined selection in carioca beans for grain size, slow darkening and fastcooking after storage times. Euphytica, v.214, art.66, 2018. DOI: https://doi.org/10.1007/s10681-018-2149-8.

CORRÊA, A.M.; TEODORO, P.E.; GONÇALVES, M.C.; SANTOS, A.; TORRES, F.E. Selection of common bean (Phaseolus vulgaris L.) genotypes using a genotype plus genotype $\mathrm{x}$ environment interaction biplot. Genetics and Molecular Research, v.15, gmr8427, 2016. DOI: https://doi.org/10.4238/gmr.15038427.

COUTIN, J.A.F.; MUNHOLLAND, S.; SILVA, A.; SUBEDI, S.; LUKENS, L.; CROSBY, W.L.; PAULS, K.P.; BOZZO, G.G. Proanthocyanidin accumulation and transcriptional responses in the seed coat of cranberry beans (Phaseolus vulgaris L.) with different susceptibility to postharvest darkening. BMC Plant Biology, v.17, art.89, 2017. DOI: https://doi.org/10.1186/s12870017-1037-z.

DELFINI, J.; CIRINO, V.M.; RUAS, C. de F.; RUAS, P.M.; SANTOS NETO, J. dos; GONÇALVES, L.S.A. Estimation of genetic parameters and prediction of genotypic values in common beans using mixed models. Emirates Journal of Food and Agriculture, v.30, p.1026-1035, 2018. DOI: https://doi.org/10.9755/ejfa.2018.v30.i12.1884.

DI PRADO, P.R.C.; FARIA, L.C.; SOUZA, T.L.P.O.; MELO, L.C.; MELO, P.G.S.; PEREIRA, H.S. Genetic control and selection of common bean parents and superior segregant populations based on high iron and zinc contents, seed yield and 100-seed weight. Genetics and Molecular Research, v.18, gmr18146, 2019. DOI: https://doi.org/10.4238/gmr18146.

ELSADR, H.T.; WRIGHT, L.C.; PAULS, K.P.; BETT, K.E. Characterization of seed coat post harvest darkening in common bean (Phaseolus vulgaris L.). Theoretical and Applied Genetics, v.123, p.1467-1472, 2011. DOI: https://doi.org/10.1007/s00122-011-1683-8.

ELSTON, R.C. A weight-free index for the purpose of ranking or selection with respect to several traits at a time. Biometrics, v.19, p.85-97, 1963. DOI: https://doi.org/10.2307/2527573.

EMBRAPA. Empresa Brasileira de Pesquisa Agropecuária. Dados de conjuntura da produção de feijão comum (Phaseolus vulgaris L.) no Brasil: 1985 a 2019. Available at: <http://www. cnpaf.embrapa.br/socioeconomia/index.htm>. Accessed on: June 282021.

ERFATPOUR, M.; NAVABI, A.; PAULS, K.P. Mapping the non-darkening trait from 'Wit-rood boontje' in bean (Phaseolus vulgaris). Theoretical and Applied Genetics, v.131, p.1331-1343, 2018. DOI: https://doi.org/10.1007/s00122-018-3081-y.

FAO. Food and Agriculture Organization of the United Nations. Production yearbook. Available at: <http://faostat3.fao.org/>. Accessed on: June 282021.

JUNK-KNIEVEL, D.C.; VANDENBERG, A.; BETT, K.E. Slow darkening in pinto bean (Phaseolus vulgaris L.) seed coats is controlled by a single major gene. Crop Science, v.48, p.189-193, 2008. DOI: https://doi.org/10.2135/cropsci2007.04.0227.

MELO, L.C. (Ed.). Procedimentos para condução de experimentos de valor de cultivo e uso em feijoeiro-comum. 
Santo Antônio de Goiás: Embrapa Arroz e Feijão, 2009. 104p. (Embrapa Arroz e Feijão Documentos, 239).

NUNES, J.A.R.; RAMALHO, M.A.P.; ABREU, Â. de F.B. Graphical method in studies of adaptability and stability of cultivars. Annual Report of the Bean Improvement Cooperative, v.48, p.182-183, 2005.

PEREIRA,H.S.;ALMEIDA, V.M.de;MELO,L.C.; WENDLAND, A.; FARIA, L.C. de; DEL PELOSO, M.J.; MAGALDI, M.C. de S. Influência do ambiente em cultivares de feijoeiro-comum em cerrado com baixa altitude. Bragantia, v.71, p.165-172, 2012. DOI: https://doi.org/10.1590/S0006-87052012005000024.

PEREIRA, H.S.; ALVARES, R.C.; MELO, L.C.; COSTA, A.F. da; CARVALHO, H.W.L. de. Culinary and nutritional quality of common bean lines with Carioca grain type and interaction with environments. Revista Ceres, v.64, p.159-166, 2017a. DOI: https://doi.org/10.1590/0034-737X201764020008.

PEREIRA, H.S.; ALVARES, R.C.; SILVA, F. de C.; FARIA, L.C. de; MELO, L.C. Genetic, environmental and genotype $\mathrm{x}$ environment interaction effects on the common bean grain yield and commercial quality. Semina: Ciências Agrárias, v.38, p.1241-1250, 2017b. DOI: https://doi.org/10.5433/16790359.2017v38n3p1241.

PEREIRA, H.S.; DEL PELOSO, M.J.; SOUZA, T.L.P.O. de; FARIA, L.C. de; AGUIAR, M.S. de; WENDLAND, A.; COSTA, J.G.C. da; DÍAZ, J.L.C.; MAGALDI, M.C. de S.; ABREU, Â. de F.B.; PEREIRA FILHO, I.A.; ALMEIDA, V.M. de; MARTINS, M.; MELO, L.C. BRS FS305 - common bean cultivar with calima bean for export. Functional Plant Breeding Journal, v.3, p.7579, 2021. DOI: https://doi.org/10.35418/2526-4117/v3n1a8.

PEREIRA, H.S.; FARIA, L.C.; WENDLAND, A.; COSTA, J.G.C.; SOUZA, T.L.P.O; MELO, L.C. Genotype by environment interaction for disease resistance and other important agronomic traits supporting the indication of common bean cultivars. Euphytica, v.214, art.12, 2018. DOI: https://doi.org/10.1007\%2Fs10681-017-2093-z.

PIMENTEL-GOMES, F. Curso de estatística experimental. 14.ed. Piracicaba: Nobel, 2000. 477p.

RAMALHO, M.A.P.; ABREU, A. de F.B.; SANTOS, J.B. dos; NUNES, J.A.R. Aplicações da genética quantitativa no melhoramento de plantas autógamas. Lavras: UFLA, 2012. $522 \mathrm{p}$.

RESENDE, M.D.V. de; DUARTE, J.B. Precisão e controle de qualidade em experimentos de avaliação de cultivares. Pesquisa Agropecuária Tropical, v.37, p.182-194, 2007.

RODRIGUES, L.L.; RODRIGUES, L.A.; SOUZA, T.L.P.O. de; MELO, L.C.; PEREIRA, H.S. Genetic control of seed coat darkening in common bean cultivars from three market classes. Crop Science, v.59, p.2046-2054, 2019. DOI: https://doi.org/10.2135/cropsci2019.03.0161.

SILVA, F. de C.; PEREIRA, H.S.; MELO, P.G.S.; MELO, L.C. Selection of parents and segregating populations of common bean with high agronomic potential and slow seed-coat darkening. Pesquisa Agropecuária Tropical, v.48, p.75-82, 2018. DOI: https://doi.org/10.1590/1983-40632018v4849519.

SILVA, F.C.; MELO, P.G.S.; PEREIRA, H.S.; MELO, L.C. Genetic control and estimation of genetic parameters for seed-coat darkening of carioca beans. Genetics and Molecular Research, v.13, p.6486-6496, 2014. DOI: https://doi.org/10.4238/2014. August.25.12.

SILVA, G.S. da; RAMALHO, M.A.P.; ABREU, Â. de F.B.; SILVA, F.B. Genetic control of early grain darkening of carioca common bean. Crop Breeding and Applied Biotechnology, v.8, p.299-304, 2008. DOI: https://doi.org/10.12702/1984-7033.v08n04a07.

SIQUEIRA, B.S.; PEREIRA, W.J.; BATISTA, K.A.; OOMAH, B.D.; FERNANDES, K.F.; BASSINELLO, P.Z. Influence of storage on darkening and hardening of slow- and regulardarkening carioca bean (Phaseolus vulgaris L.) genotypes. Journal of Agricultural Studies, v.2, p.87-104, 2014. DOI: https://doi.org/10.5296/jas.v2i2.5859.

SOUZA, T.L.P.O.; FARIA, J.C.; ARAGÃO, F.J.L.; DEL PELOSO, M.J.; FARIA, L.C.; WENDLAND, A.; AGUIAR, M.S.; QUINTELA, E.D.; MELO, C.L.P.; HUNGRIA, M.; VIANELLO, R.P.; PEREIRA, H.S.; MELO, L.C. Agronomic performance and yield stability of the RNA interference-based Bean golden mosaic virus-resistant common bean. Crop Science, v.58, p.579-591, 2018. DOI: https://doi.org/10.2135/cropsci2017.06.0355. 